\title{
PSYCHOLOGY IN PERSPECTIVE
}


Also by Nicky Hayes

FOUNDATIONS OF PSYCHOLOGY

A FIRST COURSE IN PSYCHOLOGY

PSYCHOLOGY: An Introduction (with Sue Orrell)

PSYCHOLOGY: Theory and Application

(with Philip Banyard)

A STUDENTS DICTIONARY OF PSYCHOLOGY

(with Peter Stratton)

PRINCIPLES OF SOCIAL PSYCHOLOGY

THE GCSE SURVIVAL GUIDE

INVESTIGATING PSYCHOLOGY (with Irene Taylor)

TEACH YOURSELF PSYCHOLOGY 


\title{
Psychology in Perspective
}

\author{
Nicky Hayes \\ Honorary Research Fellow \\ School of Human and Health Sciences \\ The University of Huddersfield
}

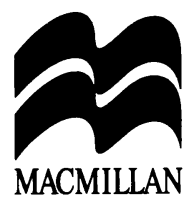


(C) Nicky Hayes 1995

All rights reserved. No reproduction, copy or transmission of this publication may be made without written permission.

No paragraph of this publication may be reproduced, copied or transmitted save with written permission or in accordance with the provisions of the Copyright, Designs and Patents Act 1988, or under the terms of any licence permitting limited copying issued by the Copyright Licensing Agency, 90 Tottenham Court Road, London W1P 9HE.

Any person who does any unauthorised act in relation to this publication may be liable to criminal prosecution and civil claims for damages.

First published 1995 by

\section{MACMILLAN PRESS LTD}

Houndmills, Basingstoke, Hampshire RG21 2XS

and London

Companies and representatives

throughout the world

ISBN 978-0-333-60686-5 ISBN 978-1-349-23862-0 (eBook)

DOI 10.1007/978-1-349-23862-0

A catalogue record for this book is available from the British Library.

$\begin{array}{llllllllll}10 & 9 & 8 & 7 & 6 & 5 & 4 & 3 & 2 & 1\end{array}$

$\begin{array}{llllllllll}04 & 03 & 02 & 01 & 00 & 99 & 98 & 97 & 96 & 95\end{array}$

Copy-edited and typeset by Povey-Edmondson

Okehampton and Rochdale, England 
To Chris Lenton 


\section{Contents}

List of Figures

ix

Acknowledgements $\quad$ xi

Preface

xiii

1 Reductionism in Psychological Theory 1

Behaviourism 3

Neurological reductionism $\quad 8$

Genetic determinism $\quad 12$

Social reductionism $\quad 15$

Reductionism as a general approach $\quad 16$

2 The Influence of Behaviourism 19

Behaviourism in its times $\quad 19$

The influence of behaviourism 23

Challenges to behaviourism $\quad 27$

Levels of explanation $\quad 30$

Alternatives to behaviourism 31

3 Ethical Issues in Psychological Research 35

Ethical questions raised by past psychological research $\quad 37$

Re-evaluating research practices 41

Animal studies $\quad 45$

Ethical questions about practical work $\quad 48$

Ethical issues raised by general perspectives and

4 Changing Values in Psychological Knowledge 53

The nature of introductory psychology courses $\quad 55$

Adapting research techniques $\quad 56$

A new methodology $\quad 58$

Social responsibility of science $\quad 60$ 


\section{viii Contents}

5 Perspectives in Social Psychology 63

Traditional social psychology $\quad 63$

$\begin{array}{ll}\text { Levels of explanation } & 70\end{array}$

European social psychology $\quad 73$

Theories in European social psychology 75

6 European Social Psychology 77

The growth of European Social Psychology 80

Social representation theory $\quad 81$

Social identity theory $\quad 85$

Attribution theory $\quad 89$

7 Ecopsychology $\quad 93$

8 Perspectives in Cognitive Psychology 105

Two traditions within cognitive psychology 107

Cognitive psychology and the computer metaphor $\quad 109$

Cognitive psychology and 'objective' science 114

Cognitive psychology and other areas of psychological understanding

9 The Politics of Nature and Nurture 123

The philosophical background 123

Nature and nurture in psychological theory $\quad 126$

$\begin{array}{ll}\text { Problems of nativist arguments } & 137\end{array}$

10 The 'Magic' of Sociobiology 141

Sociobiological theory 142

Sociobiological explanation $\quad 144$

Sociobiology as magic $\quad 148$

Evolution and behaviour: an alternative view $\quad 151$

So why is sociobiology so popular? 158

$\begin{array}{ll}\text { Glossary } & 163\end{array}$

$\begin{array}{ll}\text { Bibliography } & 169\end{array}$

$\begin{array}{ll}\text { Index } & 179\end{array}$ 


\section{List of Figures}

1.1 The Necker cube 6

1.2 The 'rat-man' figure 7

6.1 American social psychology 82

6.2 European social psychology 82

7.1 Neisser's cognitive cycle 95

10.1 Evolutionary development of the brain 152 


\section{Acknowledgements}

This book is the product of a number of lectures delivered to psychology students, and others, between 1986 and 1993. I am grateful to all of those, both teachers and students, whose interest and enthusiasm showed me that this activity was worth pursuing. Special thanks must go to the many psychology lecturers who gave up their free time and energy to organise revision workshops for psychology students all over the country, and to the Association for the Teaching of Psychology for encouraging these events. I would also like to express my appreciation of the personal encouragement and support which I have received in this undertaking, from so many people.

The views expressed in this book are entirely my own, but I would like to acknowledge my considerable debt to Steven Rose, both for inspiration, and for providing a role-model for a much-needed critique of scientific activity, located within a scientific context.

The papers which constitute the chapters of this book have been delivered at various conferences and workshops. An earlier version of the chapter 'The "Magic" of Sociobiology' was published in the ATP journal Psychology Teaching in 1986.

\section{Sources}

Ultimately, the origin of this book lies in the many student revision workshops organised by the Association for the Teaching of Psychology, Nottingham Psychology Conferences, and others, during the period 1986-93. I am grateful to their organisers for giving me the opportunity to develop these ideas, and to the students who attended them for showing me that the ideas were appreciated. The main point of origin for each chapter is given below: 


\section{xii Acknowledgements}

Chapter 1 developed from a lecture first given at the Association for the Teaching of Psychology Student Revision Conferences in Spring 1987.

Chapter 2 developed from a lecture first given at the Association for the Teaching of Psychology Student Revision Conferences in Spring 1989.

Chapter 3 developed from a lecture first given at the Association for the Teaching of Psychology Student Revision Conferences in Spring 1990.

Chapter 4 is the text of a paper given at the British Psychological Society's London Conference in December 1992.

Chapter 5 developed from a lecture first given at the Association for the Teaching of Psychology Student Revision Conferences in Spring 1993.

Chapter 6 developed from a lecture first given at the Association of Psychology Annual Conference in July 1991.

Chapter 7 is an extension of an article which originally appeared in Psychology News, vol. 2, no. 5, in 1989.

Chapter 8 developed from a lecture first given at the Association for the Teaching of Psychology Student Revision Conferences in Spring 1990.

Chapter 9 developed from a lecture first given at the Association for the Teaching of Psychology Student Revision Conferences in Spring 1988.

Chapter 10 developed from a article first published in the Association for the Teaching of Psychology journal, Psychology Teaching, 1986 (2), 2-16. 


\section{Preface}

Science is not value-free. It exists in society, and it reflects society's assumptions. Research funding, scientific publication and the scientific community's decisions about what counts as valid knowledge all reflect the social contexts in which they take place. Psychology is not exempt from these processes. Like the other sciences, psychology exists in a social context, and its concerns are also those of its wider society. Psychology's internal development - its theories, its evidence and its subject matter - all mirror those concerns, as well as contributing to them, both directly and indirectly.

Psychology is a living discipline. It has its own history, its own current concerns, and its own future trends. But looking only at the present is not enough to explain why modern psychology is like it is. If we are going to understand its concerns and conflicts, we also need to understand its history and the social movements which have shaped that history. Psychology in Perspective surveys a number of different aspects of psychology's history, looking at both the internal and the external developments which have shaped it.

Psychology in Perspective has a broad scope. Its ten essays encompass philosophical theories, schools of thought, social movements and human potential. In this book I have challenged several of the psychological manifestations of reductionist and repressive ideologies, both on ideological and scientific grounds. At the same time, I have tried to present some of the alternatives: to criticise without presenting alternatives is a sterile exercise, in my view. I have tried to show how patterns of thinking emerged within the psychological discipline, and how they exerted their influences on subsequent generations. I have also tried to show how they were shaped by wider social developments, and in turn contributed to accepted social knowledge - and not always in positive ways. As scientists, we cannot evade our social responsibilities by turning away from some of the less 


\section{xiv Preface}

palatable truths about our history. Rather, we need to be fully aware of the social implications of what we are doing, and what our predecessors have done.

NiCKY HAYES 